\title{
PENGEMBANGAN KOPERASI KOTA BANDUNG MELALUI PEMETAAN PELAKU USAHA KOPERASI DAN USAHA UNGGULANNYA
}

\author{
Asep Mulyana \\ Program Studi Manajemen FEB Universitas Padjadjaran \\ e-mail: asep.mulyana@fe.unpad.ac.id \\ Wa Ode Zusnita Muizu \\ Program Studi Manajemen FEB Universitas Padjadjaran \\ e-mail: waode.zusnita@fe.unpad.ac.id
}

\begin{abstract}
ABSTRAKSI
Krisis yang terjadi di Indonesia pada 1997, dilanjutkan dengan krisis ekonomi dunia pada tahun 2008 serta krisis Eropa di Yunani pada tahun 2012, Usaha besar satu persatu gulung tikar karena bahan baku impor meningkat secara drastis, biaya cicilan utang meningkat sebagai akibat dari nilai tukar rupiah terhadap dolar yang menurun. Diluar dugaan, ternyata UKM dan koperasi di Indonesia yang dianggap kecil justru dapat menghadapi keadaan krisis ini. UKM dan Koperasi malah mampu eksis dan berperan sebagai jangkar ekonomi di Indonesia.

Tujuan dari penelitian ini mengidentifikasi posisi koperasi berdasarkan daya tarik pasar dan sumber daya dan profil Inventarisasi andalan bisnis koperasi didasarkan pada komitmen dan kompetensi bisnis koperasi dalam menjalankan usaha koperasi

Penelitian ini menggunakan analisis deskriptif, dengan menggunakan dua (2) pendekatan, (1) literatur study ; dan (2) Survey (wawancara, diskusi kelompok dan observasi). Data survei dilakukan di 75 koperasi dan Satuan Kerja Pemerintah Daerah di Kota Bandung

Penelitian ini menyimpulkan Koperasi di Kota Bandung dalam posisi pertumbuhan, yang membedakan koperasi kota Bandung dengan koperasi di kota-kota lain adalah: 1) padat karya; 2) keterampilan tradisional sederhana.; 3) Produk Budaya; 4) Struktur modal berasal dari ekuitas dan pinjaman dari sumber informal; 5) Cepat dan respon yang fleksibel; 6) Kreatif dan Inovatif
\end{abstract}

Kata Kunci : Pemetaan Koperasi, Komitmen, Kompetensi 


\section{PENDAHULUAN}

Krisis keuangan global dan efek pasar bebas ini sering jadi ancaman bagi perekonomian sebuah negara. Banyak perusahaan yang tidak mampu lagi meneruskan usaha karena tingkat bunga yang tinggi. Diluar dugaan, ternyata UKM dan koperasi di Indonesia yang dianggap kecil justru sebaliknya dapat menahadapi keadaan krisis ini. UKM dan Koperasi malah mampu eksis dan berperan sebagai jangkar ekonomi di Indonesia. Resistensinya terbukti mampu menjadi perisai penyedia lapangan kerja di masa-masa yang sulit serta melapangkan jalan bagi usahausaha yang berskala lebih besar untuk pulih dari keterpurukan.

Data Kementerian Koperasi dan UMKM menunjukkan pada 2012, total UMKM mencapai 56,5 juta unit atau setara dengan 99,9\% dari total unit usaha di Indonesia, sedangkan jumlah koperasi di Indonesia mencapai 200.808 unit. Di Kota Bandung sendiri, esensi dan eksistensi usaha kecil dan koperasi dalam perekonomian kota Bandung tidak perlu diragukan lagi. Usaha kecil dan koperasi yang tersebar di lima wilayah kota Bandung telah mampu menyerap sumber daya dan tenaga kerja local.

Data Kementerian Koperasi dan Usaha Kecil Menengah (UKM), kontribusi koperasi terhadap produk domestik bruto (PDB) hanya 2 persen, jauh dibandingkan kontribusi badan usaha milik negara (BUMN) yang sebesar 20 persen.koperasi di Indonesia belum mencapai kondisi idealnya, karena belum adanya perlindungan dan dukungan usaha yang optimal yang disebabkan oleh beragam persoalan klasik, seperti lemahnya kualitas sumber daya manusia, keterbatasan modal, networking, teknologi penanganan usaha, dan pemasaran produk. Tantangan lainnya adalah tahun 2015, akan mulai diberlakukan ASEAN Free Trade Area(AFTA).

Persoalan-persoalan yang dihadapi oleh koperasi ini, hendaknya ditangani secara serius, jika sekiranya koperasi masih diinginkan untuk menjadi teladan bagi kemajuan perekonomian nasional. Oleh karena itu perlu dilakukan pengidentifikasian posisi koperasi kota Bandung yang tidak saja berbasis pada sumber daya tetapi juga juga melihat prospek ke depannya, khususnya mengenai pasar dengan melakukan pemetaan koperasi unggulan berdasarkan pelaku usahanya dan usaha unggulannya adalah hal yang tidak bisa ditawar-tawar lagi agar penanganan masalahnya dapat dihasilkan dan I Msesuai dengan harapan para pelaku usaha koperasi

Berdasarkan uraian pada latar belakang di atas, maka tujuan yang ingin dicapai dari penelitian ini adalah :

1. Mengidentifikasi posisi koperasi unggulan berdasarkan daya tarik pasar dan sumber daya yang dimilikinya

2. Menginventarisir profil pelaku usaha koperasi andalan berdasarkan komitmen dan kompetensi pelaku usaha koperasi dalam menjalankan kegiatan usaha koperasinya

Dalam rangka mencapai tujuan penelitian yang telah diuraikan di atas, maka dilakukan serangkaian kegiatan mulai dari penentuan variable penelitian, pengumpulan data, 
pengolahan data, dan evaluasi serta penetapan kerangka luaran, yang menjadi dasar dalam melakukan analisis lebih lanjut.

\section{LANDASAN TEORI}

Koperasi adalah lembaga yang tumbuh atas dasar solidaritas tradisional dan kerjasama antar individu, yang memiliki peran strategis dalam pengguatan perekonomian rakyat.

Organisasi Buruh Sedunia (Intemational Labor Organization/ILO), dalam resolusinya nomor 127 yang dibuat pada tahun 1966, membuat batasan mengenai ciri-ciri utama koperasi yaitu : merupakan perkumpulan orang-orang; Yang secara sukarela bergabung bersama; Untuk mencapai tujuan ekonomi yang sama; Melalui pembentukan organisasi bisnis yang diawasi secara demokratis; Yang memberikan kontribusi modal yang sama dan menerima bagian resiko dan manfaat yang adil dari perusahaan di mana anggota aktifberpartisipasi.

Undang-undang Republik Indonesia Nomor 25 Tahun 1992 Tentang Perkoperasian mendefinisikan koperasi sebagai Badan Usaha yang beranggotakan orang-seorang atau badan badan hukum koperasi dengan melandaskan kegiatannya berdasarkan prinsip koperasi sekaligus sebagai gerakan ekonomi rakyat yang berdasarkan asas kekeluargaan. Tujuan utama Koperasi Indonesia adalah mengembangkan kesejahteraan anggota, pada khususnya, dan masyarakat pada umumnya. Koperasi Indonesia adalah perkumpulan orangorang, bukan perkumpulan modal sehingga laba bukan merupakan ukuran utama kesejahteraan anggota. Manfaat yang diterima anggota lebih diutamakan daripada laba. Meskipun demikian harus diusahakan agar koperasi tidak menderita rugi. Tujuan ini dicapai dengan karya dan jasa yang disumbangkan pada masing-masing anggota. "Keanggotaan Koperasi Indonesia bersifat sukarela dan didasarkan atas kepentingan bersama sebagai pelaku ekonomi. Melalui koperasi, para anggota ikut, secara aktif memperbaiki kehidupannya dan kehidupan masyarakat melalui karya dan jasa yang disumbangkan

Dalam usahanya, koperasi akan lebih menekankan pada pelayanan terhadap kepentingan anggota, baik sebagai produsen maupun konsumen. Kegiatan koperasi akan lebih banyak dilakukan kepada anggota dibandingkan dengan pihak luar. Oleh karena itu, anggota dalam koperasi, bertindak sebagai pemilik sekaligus pelanggan.”(SAK,1996:27.1) Menurut Undang-Undang Nomor 25 Tahun 1992 Pasal 3 tujuan koperasi Indonesia adalah "koperasi bertujuan memajukan kesejahteraan anggota pada khususnya dan masyarakat pada umumnya serta ikut membangun tatanan perekonomian nasional dalam rangka mewujudkan masyarakat yang maju, adil dan makmur berlandaskan Pancasila dan UndangUndang Dasar 1945".

\section{Kompetensi}

Kompetensi adalah karakteristik yang mendasari seseorang berkaitan dengan efektivitas kinerja individu dalam pekerjaannya atau karakteristik dasar yang memiliki hubungan kasual atau sebagai sebab-akibat dengan kriteria yang dijadikan acuan, efektif atau berkinerja prima atau superior di tempat kerja atau pada situasi tertentu (Mitrani et. Al : 1992)

Hirley Fletcher (2002), menjelaskan bahwa: (i) kompetensi didasarkan pada analisis peran profesional dan atau formulasi tanggung jawab profesional; (ii) pernyataan kompetensi menjelaskan hasil yang diharapkan dari kinerja dari fungsi yang terkait 
secara profesional, pengetahuan, keterampilan dan sikap yang sangat penting untuk kinerja fungsi tersebut; (iii) pernyataan kompetensi memfasilitasi penilaian berpatokan pada kriteria; (iv) kompetensi diperlukan sebagai alat prediksi (predictor) tentatif atas efektivitas profesional; (v) kompetensi ditetapkan dan diumumkan sebelum diberlakukan; (vi) kompetensi adalah peran yang diturunkan, ditetapkan dalam bentuk perilaku yang diamati. Dari penjelasan ini, dapat disimpulkan bahwa kompetensi ini terkait dengan profesioanalisme, tentang kinerja yang superior, tentang indikator-indikator dari suatu kompetensi dan fungsi dari kompetensi sebagai prediktor dari kinerja yang superior.

Spencer and Spencer (1993 : 9-11) membagi karakteristik kompetensi menjadi 5 (lima) karakteristik ang akan membedakan dan menentukan antara orang yang mempunyai kinerja yang superior atau rata-rata, atau kinerja yang efektif dengan yang tidak efektif YAKNI 1) Motif (Motives), 2) Watak (Traits), 3) Konsep Diri (Self Concept), 4) Pengetahuan (knowledge) dan 5) Keahlian (Skills), sedangkan Katz dalam Schermerhorn (1994) membagi skill dalam tiga Kategori 1) Technical skill 2) Human skill 3) Conceptual skill

Penerapan kompetensi tidak dapat dipisahkan dari kemampuan seseorang menggunakan pemikiran intelektual dan mengendalikan emosinya. Bergerhenegouwen (1997) dan Marshall (2003) dalam Winanti (2011) menjelaskan bahwa kompetensi merupakan hal yang paling sulit ditiru, karena karakteristiknya yang memang berbeda dan spesifik bagi masing-masing individu. Sejalan dengan pendapat tersebut, Munro dan Andrews (1994) dalam Winanti (2011) menegaskan bahwa di era hiper kompetitif berbasis pengetahuan seperti yang terjadi sekarang ini, kompetensi merupakan aset utama perusahaan sebagai sumber untuk membangun dan meraih keunggulan bersaing secara berkelanjutan.

Robbin (2003) juga berpendapat bahwa keterampilan dapat dibagi ke dalam tiga kategori, yaitu: (a) keterampilan teknis yang pada umumnya diperoleh melalui program pelatihan dengan tujuan memperbaiki keterampilan teknis karyawan.

Pelatihan teknis telah menjadi semakin penting, hal ini antara lain disebabkan karena teknologi baru dan rancangan struktur baru; (b) keterampilan hubungan antar pribadi, yang bisa dilihat dari sejauh mana kemampuan individu berinteraksi secara efektif dengan rekan sekerja dan atasan mereka; (c) keterampilan dalam memecahkan masalah. Pemecahan masalah mencakup kegiatan mempertajam logika, penalaran dan keterampilan me ndefinisikan masalah, maupun kemampun mereka menilai sebab dan akibat, mengembangkan alternatif, menganalisis alternatif dan memilih pemecahan.

Kompetensi sumberdaya manusia dapat dibedakan menjadi dua (Mitrani, et. Al and Fitt : 1992), yaitu: (i) kompetensi yang bersifat visible seperti kompetensi pengetahuan dan kompetensi keahlian; (ii) kompetensi yang bersifat invisible seperti konsep diri, sifat dan motif, yang kesemuanya dapat dikatagorikan dalam variabel sikap (attitude). 


\section{Komitmen}

Komitmen merupakan sebuah proses yang berkesinambungan, dan tidak begitu saja terjadi, dan merupakan sebuah pengalaman individu ketika bergabung dalam organisasi (Grant, Amstrong, 1994, dalam Sopiah, 2008).

Mowday, Porter, dan Steers (1982) mengatakan bahwa karyawan yang memiliki komitmen organisasi yang tinggi akan lebih termotivasi untuk hadir dalam organisasi dan berusaha mencapai tujuan organisasi. Dalam komitmen organisasi tercakup unsur loyalitas terhadap organisasi, keterlibatan dalam pekerjaan, dan identifikasi terhadap nilai-nilai dan tujuan organisasi.

Rendahnya komitmen mencerminkan kurangnya tanggung jawab seseorang dalam menjalankan tugasnya. Steers (dalam Sopiah, 2008) menyatakan tiga faktor yang mempengaruhi komitmen seorang karyawan antara lain: Ciri pribadi pekerja, Ciri pekerjaan, Pengalaman kerja, Sementara itu, Minner (dalam Sopiah, 2008) mengemukakan empat faktor yang mempengaruhi komitmen karyawan antara lain:

1. Faktor personal, misalnya usia, jenis kelamin, tingkat pendidikan, pengalaman kerja dan kepribadian

2. Karakteristik pekerjaan, misalnya lingkup jabatan, tantangan dalam pekerjaan, konflik peran, tingkat kesulitan dalam pekerjaan

3. Karakteristik struktur, misalnya besar kecilnya organisasi, bentuk organisasi, kehadiran serikat pekerjan, dan tingkat pengendalian yang dilakukan organisasi terhadap karyawan

4. Pengalaman kerja. Pengalaman kerja seorang karyawan sangat berpengaruh terhadap tingkat komitmen karyawan pada organisasi. Karyawan yang baru beberapa tahun bekerja dan karyawan yang sudah puluhan tahun bekerja dalam organisasi tentu memiliki tingkat komitmen yang berlainan

Komitmen terhadap organisasi artinya lebih dari sekedar keanggotaan formal, karena meliputi sikap menyukai organisasi dan kesediaan untuk mengusahakan tingkat upaya yang tinggi bagi kepentingan organisasi demi pencapaian tujuan.

Berdasarkan definisi ini, dalam komitmen organisasi tercakup unsur loyalitas terhadap organisasi, keterlibatan dalam pekerjaan, dan identifikasi terhadap nilai-nilai dan tujuan organisasi. Rendahnya komitmen mencerminkan kurangnya tanggung jawab seseorang dalam menjalankan tugasnya. Mempersoalkan komitmen sama

dengan mempersoalkan tanggung jawab, dengan demikian, ukuran komitmen seorang pimpinan yang dalam hal ini adalah kepala sekolah adalah terkait dengan pendelegasian wewenang (empowerment). Dalam konsep ini pimpinan dihadapkan pada komitmen untuk mempercayakan tugas dan tanggung jawab ke bawahan. Sebaliknya, bawahan perlu memiliki komitmen untuk meningkatkan kompetensi diri. 


\section{Daya Tarik Pasar}

Peran industri strategis sangatlah penting, khususnya sebagai penunjang industri pengolahan menuju industri berteknologi tinggi, menciptakan sinergi dan mempersiapkan pembangunan prasarana yang lengkap dalam rangka mendukung pembangunan ekonomi nasional dan membangun industri pertahanan yang dibutuhkan. Sisi ironi yang terjadi adalah sedemikian pentingnya peran sektor industri ini akan tetapi lebih dari 10 tahun terakhir sektor industri strategis malah semakin terpuruk. Fakta yang ada dari hasil survey pendahuluan (Maret, 2012), pada umumnya Unit-unit Bisnis Industri Strategis masih sulit untuk mencapai target penjualan capaian target pada umumnya dalam kurun waktu lima tahun terakhir sulit mencapai $80 \%$, apa lagi mencapai $100 \%$ atau lebih. Keuntungan yang diperoleh masih kecil dan bahkan ada beberapa Unit Bisnis yang merugi. Tidak optimalnya kinerja bisnis industri strategis berbasis pertahanan dewasa ini diduga disebabkan karena masih memiliki kelemahan dalam perancangan strategi bersaing serta penciptaan kreasi nilai (value creation) cenderung belum sepenuhnya mengacu kepada tuntutan pasar, serta disamping itu tidak maksimalnya kinerja bisnis industri strategis, juga ditunjang oleh belum mampunya pihak manajemen mengekplorasi daya tarik pasar di wilayah operasinya secara optimal, serta masih banyak peluang bisnis yang tampaknya masih sulit untuk dimanfaatkan

Kesuksesan industri sangat ditentukan oleh sejauhmana perusahaan mampu menciptakan daya tarik pasar. Daya tarik pasar menurut Kotler (2006) menetapkan sembilan dimensi yaitu : (i) Overall market size, (ii) Annual market growth rate, (iii) Historical profit margin, (iv) Competitive intensity, (v) Technological requirements, (vi) Inflationary vulnerability, (vii) Energy requirements, (viii) Environmental impact, dan (ix) Social-political - legal.

Penciptaan daya tarik pasar tidak terlepas dari kemampuan perusahaan menentukan posisi dalam persaingan pasar yang makin kompetitif. Oleh karena itu industri kreatif perlu menetapkan strategi persaingan. Dalam hal ini Porter (2006) mentapkan lima fakor kunci yang berpengaruh secara langsung dalam menentukan posisi persaingan dalam pasar bebas

Daya tarik pasar merupakan potensi dan keuntungan dari koperasi yang merupakan fungsi dari interaksi antara lingkungan eksternal, kekuatan pesaing, kekuatan konsumen, kekuatan pemasok, kekuatan perantara, ukuan pasar, dan pertumbuhan industri kreatif. Daya tarik usaha koperasi terdiri atas peluang dan ancaman yang bersumber dari kebijakan pemerintah, lingkungan ekonomi, demografi, teknologi, sosial budaya, sumber daya alam, politik, hukum, kekuatan konsumen, kekuatan pemasok dan kekuatan perantara.

Dengan menggunakan model Porter tersebut, maka prediksi terhadap munculnya elemen lain yang ikut bermain dalam persaingan usaha dapat dideteksi perusahaan menciptakan daya tarik tersendiri terhadap segmen pasar yang dilayani.

Usaha koperasi diharapkan memiliki fleksibilitas dalam menghadapi tuntutan lingkungan bisnis agar dapat memiliki keunggulan bersaing. Keseimbangan antara sumber daya internal yang dimiliki dengan gejolak perubahan lingkungan eksternal adalah salah satu syarat yang harus dipenuhi oleh organisasi koperasi agar dapat menciptakan organisasi yang berdaya saing. Koperasi harus menguasai informasi tentang factor ekonomi, 
teknologi, politik, social budaya, kebijakan pemerintah, persaingan, dan tuntutan konsumen. Untuk itu, meningkatkan kemampuan sumber daya internal organisasi merupakan suatu keharusan, berikut sarana dan pra sarana penunjangnya.

Daya tarik pasar merupakan potensi dan keuntungan dari koperasi yang merupakan fungsi dari interaksi antara lingkungan eksternal, kekuatan pesaing, kekuatan konsumen, kekuatan pemasok, kekuatan perantara, ukuan pasar, dan pertumbuhan industri kreatif. Daya tarik usaha koperasi terdiri atas peluang dan ancaman yang bersumber dari kebijakan pemerintah, lingkungan ekonomi, demografi, teknologi, sosial budaya, sumber daya alam, politik, hukum, kekuatan konsumen, kekuatan pemasok dan kekuatan perantara.

\section{METODOLOGI}

Untuk mencapai tujuan penelitian, diperlukan serangkaian kegiatan yang menjadi dasar dalam melakukan analisis lebih lanjut. Kegiatan tersebut dimulai dari pengumpulan data sekunder dan observasi untuk mengetahui dan menentukan profil industri kreatif dan komunitasnya.

Studi ini didesain dengan menggunakan analisis deskriptif, yaitu suatu cara pengumpulan, penyusunan, dan perancangan penelitian yang bertujuan untuk memperoleh dekripsi suatu objek, yang kemudian diinterpretasikan. Pengertian desktiptif adalah menguraikan berbagai aspek yang berhubungan dengan studi ini dan kemudian hasil temuan yang ada akan dijadikan landasan langkah kegiatan yang akan diambil untuk masa yang akan datang. Menurut Travers (1978), metoda ini bertujuan untuk menggambarkan sifat sesuatu yang tengah berlangsung pada saat penelitian dilakukan dan memeriksa sebab-sebab dari suatu gejala tertentu.

Teknik studi menggunakan 2 (dua) pendekatan, yaitu (1) Studi pustaka (Desk Study); dan (3) Survey (wawancara, FGD dan observasi). Survey data dilakukan pada 75 pelaku usaha koperasi dan anggotanya serta Satuan Kerja Pemerintah Daerah (SKPD) yang ada di Kota Bandung, yaitu Dinas UMKM, Koperasi \& Perdagangan, Bappeda. Data primer diperoleh melalui indept interview kepada pelaku usaha koperasi di Kota Bandung.variable-variabel yang akan diteliti akan disusun secara detail dalam tabel operasionalisasi variable (see appendix 1)

Koperasi yang akan disurvei merupakan populasi dari koperasi yang ada di Kota Bandung yang tersebar di lima wilayah di kota Bandung, yaitu Bandung Utara, Bandung Timur, Bandung Selatan, Bandung Tengah, dan Bandung Barat.

\section{Populasi dan sampling}

Populasi merupakan kumpulan unsur / elemen objek penelitian yang memiliki kualitaskualitas serta ciri-ciri yang telah ditetapkan (Suharsimi, 2002). Populasi dalam penelitian ini meliputi keseluruhan unit analisis yang dijadikan sumber informasi bagi indikator-indikator yang mengukur setiap variabel dalam penelitian.

Unit pengamatan utama dalam penelitian ini adalah para pelaku usaha koperasi, anggota koperasi, dan beberapa SKPD terkait yang ada di Kota Bandung.Untuk menentukan wilayah yang terpilih sebagai sampel, dengan asumsi bahwa variasi dari perilaku 
kecamatan di kota Bandung memiliki tingkat homogenitas yang tinggi, pada penelitian ini melihat pada wilayah sebaran koperasi

yang berkembang di kota Bandung yang jumlahnya 1880 (koperasi aktif) dari 2452 koperasi yang ada.

Metode penarikan sampel yang dipakai adalah Simple Random Sampling. Penentuan Sampel pelaku usaha koperasi dilakukan dengan langkah-langkah berikut :

1. Menentukan ukuran dan unit sampel survey awal. Tahap ini dilakukan untuk meyakinkan jumlah populasi sebaran koperasi di 5 (lima) wilayah tersebut di atas

2. Mengidentifikasi jumlah koperasi yang tersebar di 5 (lima) wilayah observasi

3. Menentukan dan mengalokasikan ukuran sampel berdasarkan penyebaran populasi koperasi per wilayah di Kota Bandung

4. Berdasarkan sampel yang telah dipilih menurut klasifikasi usaha koperasi, kemudian dipilih anggota sampel per wilayah di Kota Bandung

Pengumpulan data primer yang dibutuhkan sebagai objek dalam kegiatan ini, dilakukan dengan cara penyebaran kuesioner untuk menilai secara umum sejauh mana perkembangan usaha koperasi di Kota Bandung dilihat dari profil pelaku usaha koperasi andalan berdasarkan komitmen dan kompetensi. Profil koperasi unggulan berdasarkan daya tarik koperasi dan kekuatan usaha industri kreatif.

Data yang terkumpul dari hasil penyebaran kuesioner dan pengumpulan data sekunder dilakukan dalam 4 langkah yaitu data coding, data editing, data processing, dan data analysis. Seluruh data yang berhasil dikumpulkan dari pelaksanaan FGD, wawancara, dan survey lapangan, selanjutnya dianalisis berdasarkan empat kategori, yaitu :

1. Data hasil analisis SWOT pada pelaku usaha koperasi

2. Data berdasarkan tingkat kepentingan koperasi

3. Data berdasarkan kekuatan bisnis dan daya tarik koperasi

Penelitian ini juga dilengkapi dengan analisis kualitatif untuk jawaban dari masingmasing pertanyaan. Kuesioner dalam penelitian ini disusun berdasarkan itemitem yang berhubungan dengan variabel yang diteliti, menggunakan metode skor 1 sampai dengan 9. Proses analisis data hasil survey lapangan, akan diolah dengan menggunakan program komputer Microsoft Excel dan SPSS.

Tahap pelaporan merupakan tahap akhir studi dengan memasukan berbagai aspek yang perlu dianalisis serta dengan mempertimbangkan masukan, koreksian dan tanggapan dari para pemangku kepentingan. Selanjutnya adalah tahap presentasi dengan mempresentasikan hasil studi ini. 


\section{HASIL}

Visi kota bandung sebagai kota bermartabat berperan sebagai kota yang menyediakan jasa pelayanan yang didukung dengan terwujudnya keberhasilan, kemakmuran, ketaatan, kesejahteraan dan kedisiplinan masyarakat, dimana bertumpu pada potensi sumber daya dan kemampuan dengan semangat kebersamaan, tanggung jawab dan proporsional dari seluruh komponen kota. Sebagai kota yang berpotensi menopang perekonomian negara melalui koperasi yang unggul.

SKPD yang Terkait Langsung Dalam Pengembangan Koperasi di Bandung

\section{Dinas Koperasi UKM dan Perindustrian Perdagangan Kota Bandung}

Dinas Koperasi UKM dan Perindustrian Perdagangan Kota Bandung merupakan salah satu satuan kerja Perangkat Daerah yang dibentuk berdasarkan Peraturan Daerah Kota Bandung Nomor 13 tahun 2007 tentang pembentukan dan susunan dinas daerah dilingkungan pemerintah kota Bandung. Hal tersebut terbentuk sehubungan adanya perubahan paradigma penyelenggaraan kewenangan bidang pemerintahan yang semula sentralisasi menjadi desentralisasi pada Pemerintah Daerah Kabupaten/Kota dengan tujuan demokratisasi, pemberdayaan aparatur seta peningkatan pelayanan kepada masyarakat.

\section{Badan Penanaman Modal dan Pelayanan Perizinan Terpadu}

Badan Penanaman Modal dan Pelayanan Perizinan Terpadu yang selanjutnya disingkat BPMPPT adalah Badan Penanaman Modal dan Pelayanan Perizinan Terpadu Kota Bandung. BPMPPT memberikan Pelayanan Perizinan Terpadu Satu Pintu yaitu penyelenggaraan pelayanan perizinan yang proses pengelolaanya mulai dari tahap permohonan sampai ke tahap terbitnya dokumen

\section{Badan Perekonomian Sekretariat Daerah}

Pemerintah Kota Bandung, selain telah menjalankan aktivitas pemerintahanya, dalam mencapai visi kota, pemerintah ini pula memiliki wadah atau organisasi lainya diluar struktur organisasi formal. Misalnya:

P3KB (Pusat Pembinaan Promosi Pariwisata Kota Bandung) dibawah binaan Dinas Pariwisata Kota Bandung

DPE ( Dewan pengembangan Ekonomi) Kota Bandung

BPPKU ( Badan Pengelola Promosi dan Kemitraan Usaha)

Dekranasda ( Dewan Kerajinan Nasional Daerah)

Kita mengakui bahwa koperasi di Bandung baru berjalan secara perlahan menuju perkembangan, belum ada intervensi yang nyata dari pemerintah kota dan dunia perguruan tinggi di Kota Bandung. Pengembangan infrastruktur, keterampilan kewirausahaan, festival, kegiatan bazar, pasar seni, atau inkubator, cinta buatan Bandung, dan akses permodalan sudah harus menjadi program rutin bersama oleh pemerintah, komunitas kreatif dan pendidikan tinggi dalam memberikan peluang bagi khalayak ramai supaya berani mencoba berkiprah di dunia industri kreatif. Juga tentunya kesiapan pemerintah dengan kebijakan yang terpadu dan kondusif. Terutama 
perlindungan hukum dalam Hak atas Kekayaan Intelektual, lalu ada pendidikan bisnis bagi pekerja seni, pelaku industri kreatif. Bagaimana caranya menjual karya, bagaimana membuat rencana anggaran dan proposal bisnis. Juga insentif pajak yang menjanjikan.

Lingkungan dan pelaku usaha koperasi, Aturan pemerintah terhadap perkembangan koperasi, Kondisi perekonomian Indonesia saat ini merupakan peluang sekaligus hambatan yang terbesar yang dimiliki oleh koperasi, kita mengetahui bahwa tumbuh kembangnya sebuah koperasi perlu didukung oleh pemerintah untuk lebih dapat berperan didalam masyarakat, lingkungan juga menjadikan hal potensial bagi koperasiuntuk dapat berkembang namun demikian pemanfaatan potensi ini dapat saja terjadi apabila tidak adanya dukungan dari kondisi sosial masyarakat sekitarnya.

Koperasi merupakan industri yang potensial untuk dikembangkan karena koperasi memiliki sumber daya dan kemampuan yang membeedakannya dengan yang lainnya yakni intelektual SDM yang dimiliki. Tak dapat dipungkiri lagi,. Kesadaran baru telah muncul terhadap potensi yang dimiliki oleh koperasi yang mampu bertahan di tengahtengah resesi ekonomi dan mampu tumbuh berdasarkan budaya lokal.

Kehadiran koperasi memberikan peluang bagi pengelola perguruan tinggi untuk memperlengkapi para mahasiswanya untuk dapat mau dan mampu bersaing sesuai dengan tuntutan pasar. Kita butuh sarana pendidikan yang baik di bidang kreatif ini. Sekolah desain, sekolah seni, dan sekolah keterampilan dibutuhkan untuk menumbuhkan sosok pelaku dala m bidang industri berbasis pengetahuan dan ketrampilan

\section{Posisi koperasi unggulan berdasarkan daya tarik pasar dan sumber daya yang dimilikinya}

Posisi koperasi unggulan dapat dilihat pada gambar dibawah ini berdasarkan daya tarik pasar dan sumber daya yang dimiliki oleh koperasi. Berdasarkan gambar tersebut tampak jelas terlihat bahwa posisi koperasi unggulan berada pada kuadran 6

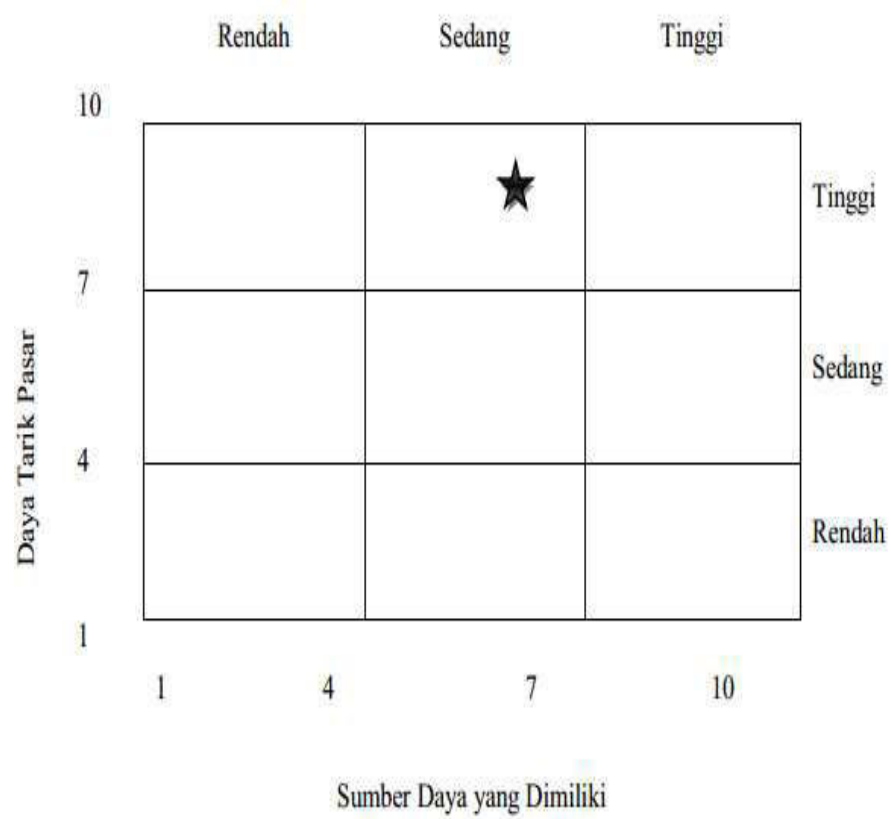


Kuadran 6 menjelaskan bahwa koperasi di kota bandung berada pada posisi pertumbuhan keatas, hal ini ditandai dengan semakin banyaknya jumlah koperasi yang ada di kota Bandung serta yang sudah berbadan hukum tetap hal ini menunjukan bahwa keandalan dan kunggulan pelaku koperasi dalam daya tarik pasar yang tinggi, sehingga berpotensi besar untuk dikembangkan dan menjadi pembina bagi perekonomian secara berkesinambungan.

Strategi pembinaan bagi para pelaku ekonomi yang berada pada kuadran iniadalah dengan memberikan bantuan teknis dan pelatihan mengenai sumber daya, sehingga membentuk keunikan sumber daya koperasi itu sendiri nantinya.Pelaku koperasi yang ada dibina dan dikembangkan dengan diberikan pelatihan tentang bidang usaha kreatif yang ditekuninya, ba ik dari segi pemasaran, SDM, produksi, maupun dalam pengelolaan keuangan, dan pelatihan mengenai motivasi dalam usaha koperasi. Mereka juga diarahkan pada peluang pasar dan sumber daya yang dimilikinya sehingga akan menciptakan suatu kepadauan untuk emnunjang kegiatan koperasi yang nantinya juga berdampak terhadap ketahanan ekonomi kedepannya.

\section{KESIMPULAN}

Berdasarkan informasi pada bab-bab sebelumnya, maka dapat disimpulkan hal-hal berikut ini:

1. Koperasi Kota Bandung diharapkan dapat menjadi motor penggerak pertumbuhan dan perkembangan kegiatan ekonomi di Kota Bandung. Berdasarkan temuan lapangan terhadap koperasi, diperoleh bahwa mayoritas koperasi berada pada jenis simpan pinjam dan koperasi usaha. Pendirian koperasi pun dilakukan berdasarkan inisiatif sendiri dan telah memiliki badan hukum tetap. Hal ini mengindikasikan bahwa para pelaku koperasi Kota Bandung memiliki komitmen yang cukup tinggi terhadap koperasi itu snediri, sekaligus dituntut untuk mampu memahami usaha yang dikelolanya berdasarkan bisnis utamanya (core compentency).

2. Kompetensi kemampuan pelaku koperasi andalan dalam menjalankan usaha dibentuk oleh proses belajar, pengalaman dan kompetensinya. Pembelajaran formal merupakan jenis pembelajaran yang menentukan kompetensi pelaku yang didukung dengan kompetensi nonformal. Dalam hal ini peranan pendidikan kursus dan pengalaman memiliki kontribusi yang besar dalam menentukan kompetensi pelaku. Sebagian besar pelaku ekonomi telah bekerja selama lebih dari sepuluh tahun dalam koperasi itu sendiri. Dalam hal kompetensi teknik, konsep dan keahlian mengelola masih terpusat pada pemilik. Masalah yang sering terjadi adalah sulitnya pengelolaan SDM yang berpengalaman dalam produksi, walaupun SDM dengan pendidikan tinggi dan potensial cukup memadai. Komitmen pelaku koperasi disemua wilayah ditunjukkan dengan sikap selalu berusaha, kesediaan berkorban, dan hasrat berkontribusi pengusaha terhadap usahanya.

3. Koperasi Kota Bandung mmemiliki target pasar yang tinggi terutama untuk permintaan untuk produk kreatif baik di Kota Bandung, nasional maupun mancanegara, dukungan SDM yang potensial, penguasaan teknologi pengusaha, meningkatnya penghargaan terhadap budaya lokal, ketersediaan SDA, meningkatnya kesadaran HAKI dan tingginya kekuatan pemasok dan perantara. Sedangkan kelemahan koperasi Kota Bandung adalah 
kurangnya dukungan peran pemerintah terhadap industri kratif, SDM yang kurang berpengalaman,siap kerja, dan sulitnya regenerasi SDM, kekurangan permodalan, sering terjadi plagiatisme yang merugikan pelaku koperasi. Secara umum, Koperasi Simpan Pinjam dan Umum merupakan koperasi unggulan kota Bandung

4. Kekuatan koperasi adalah kemampuan untuk memproduksi barang yang kreatif, inovatif dan menciptakan hal-hal baru,dan tahan terhadap gonjangan perekonomian. Kelemahan bisnis koperasi adalah produksi yang membutuhkan waktu yang relatif lama, penerapan teknologi harus lebih berhati-hati, sering terjadi inefisiensi karena domonasi penggunaan tenaga kerja manusia, sulitnya diperoleh tenaga kerja yang siap pakai dan membutuhkan waktu dan biaya yang besar untuk mendapatkan SDM yang dibutuhkan, pemasaran relatif sulit terutama untuk produk yang unik dan tersier, rendahnya penghargaan konsumen terhadap hasil industri kreatif, $\mathrm{RnD}$ belum terorganisir dengan baik.

5. Pada umunnya, pembinaan yang dilakukan relatif masih belum dapat memenuhi harapan para pelaku koperasi Kota Bandung. Sebagian besar pelaku koperasi kreatif Kota Bandung mengharapkan pembinaan yang berkesinambungan dan terarah , Sedangakan pembinaan yang dilakukan oleh para pembina lebih banyak mengarah pada aspek teknis / produksi.

6. Koperasi yang ada di Kota Bandung berada pada posisi pertumbuhan keatas, hal ini ditandai dengan semakin banyaknya jumlah koperasi yang ada di kota Bandung serta yang sudah berbadan hukum tetap hal ini menunjukan bahwa keandalan dan kunggulan pelaku koperasi dalam daya tarik pasar yang tinggi, sehingga berpotensi besar untuk dikembangkan dan menjadi pembina bagi perekonomian secara berkesinambungan.

1) Daya tarik koperasi dikota Bandung yang membedakannya dengan koperasi yang ada di kota lain di Indonesia adalah: Sangat padat karya

2) Sederhana tradisional skills.; 3)Produknya bernuansa kultur; 4) Struktur modalnya berasal dari modal sendiri dan pinjaman dari sumber informal; 5) Cepat tanggap dan fleksibel; 6)Kreatif dan Inovatif 
Asep Mulyana

Wa Ode Zusnita Muizu
Jurnal Manajemen Bisnis Indonesia

Vol. 1, Nomor 3, Juni 2014

\section{DAFTAR PUSTAKA}

Adesetya. 2010. Koperasi dan UKM Menuju Daya Saing. melalui http://bataviase.co.id/node/291907

Agung, Lilik, A.M, 2007. Human Capital Competences, PT. Elex Media Komputindo, Gramedia.

Ancok, D. (2002), Outbound Management Training: Aplikasi Ilmu Perilaku dalam Pengembangan Sumber Daya Manusia. Jogjakarta: UII Press.

Asep Suhendi. 2009. Keunggulan Kompetitif Melalui Strategi Penguasaan Wilayah, Kompetensi Sumber Daya Manusia Dan Orientasi Pasar (Studi Kasus Pada PT.Indosat Tbk). Melalui http://eprints.undip.ac.id/16105/1/ACHMAD_SOLECHAN.pdf.

Becker, B., \& Gerhart, B. 1996. The Impact of Human Resources Management on Oganizational Performance : Progress and Prospects. Academy of Management Journal, 39 (4): 779-801.Eurostat. 2001. "A Pilot Study on Co-operatives, Mutuals, Associations and Foundations", Luxembourg: Eurostat.

Fajri, M.P. 2007. Membangun GCG Sektor Koperasi melalui http://www.fcgi.or.id/en/gc_articles.shtmlLoyd, Bernard. 2001. Positioning for Peformance: Reshaping Co-ops for Success in the 21st Century. Makalah dalam Farmer Co-operative Conference, Oktober 29, Las Vegas, McKinsey \& Company

Moene, Karl Ove dan Michael Wallerstain. 1993. "Unions versus Cooperatives", dalam Samuel Bowles, Herbert Gintis, dan Bo Gustafsson (eds.), Markets and Democracy Participation, Accountability and Efficiency, Cambridge University Press.

Mowday, R.T., Porter, L.W., \& Steers, R.M. (1982). Employee-organization linkages: The psychology of commitment, absenteeism, and turnover. New York: Academic Press.

Mulyo, Jangkung Handoyo. 2004. Revitalisasi Ekonomi Kerakyatan Melalui Pemberdayaan Gerakan Koperasi. INOVASI, 2(XVI), November.

Mutis, Thoby. 2001. "Satu Nuansa, Demokrasi Ekonomi dan Ekonomi Kerakyatan", Kompas, 29 September.

Peterson, Chris. 2005. "Searching for a Cooperative Competitive Advantage". Mimeo, Michigan State University.

Riya Widayanti. 2010. Penerapan Knowledge Management Dalam Organisasi.melalui http://esaunggul.ac.id/index.php?mib=artikel.detail\&id=103\&title=Penerapan\%20Knowledge $\%$ 20Management\%20Dalam\%20Organisasi 